\title{
Relationship between postmilking standing duration and risk of intramammary infection in freestall-housed dairy cows milked 3 times per day
}

\author{
M. E. A. Watters, ${ }^{*}$ H. W. Barkema,† K. E. Leslie,‡ M. A. G. von Keyserlingk,§ and T. J. DeVries*1 \\ *Department of Animal and Poultry Science, University of Guelph, Kemptville Campus, 830 Prescott Street, Kemptville, ON, K0G 1J0, Canada \\ †Department of Production Animal Health, University of Calgary, 2500 University Dr. NW, Calgary, AB, T2N 1N4, Canada \\ fDepartment of Population Medicine, University of Guelph, 50 Stone Rd. E, Guelph, ON, N1G 2W1, Canada \\ $\S$ Animal Welfare Program, University of British Columbia, 2357 Main Mall, Vancouver, BC, V6T 1Z4, Canada
}

\begin{abstract}
Recent evidence exists to suggest that the risk of subclinical mastitis, particularly those infections caused by environmental pathogens, in dairy cows is related to standing and lying patterns. The objective of this study was to determine the association between postmilking standing duration (PMSD) of dairy cows milked $3 \times / \mathrm{d}$ and risk of intramammary infection (IMI). Four commercial freestall dairy herds in Eastern Ontario, milking $3 \times / \mathrm{d}$, were enrolled in a longitudinal study. Forty Holstein-Friesian cows per herd were randomly selected as focal animals from those cows in each herd that met our selection criteria of days in milk $(<200 \mathrm{~d})$ and somatic cell count $(<100,000$ cells $/ \mathrm{mL})$. The study consisted of three 28 -d periods. The study began following a regularly scheduled Dairy Herd Improvement test with the collection of quarter-level milk samples from all focal animals. Bacteriology was used to confirm infection status at the start of the study and for determination of incidence of IMI throughout the study. A new IMI was defined as having a culture-positive quarter-level sample when the previous sample ( $28 \mathrm{~d}$ prior) had been culture negative for the pathogen of interest. Four sets of quarter-level milk samples were obtained for each focal animal. Lying behavior was recorded for $5 \mathrm{~d}$ after each milk sampling using data loggers. For these $5 \mathrm{~d}$, individual milking times, production, and feeding times were also recorded. Postmilking standing duration was analyzed by milking event, with increased PMSD being positively associated with provision of fresh feed or freshly pushed-up feed around the time of milking, greater feed bunk space per cow, and lower freestall stocking density. Over the study period, 456 new IMI were detected, resulting in a mean herd incidence rate of 3.22 IMI per quarter year. Coagulase-negative staphylococci (CNS) and Corynebacterium spp. IMI
\end{abstract}

Received August 16, 2013.

Accepted February 12, 2014.

${ }^{1}$ Corresponding author: tdevries@uoguelph.ca were statistically analyzed to determine relationship with PMSD; they were the 2 predominant pathogens representing 45 and $31 \%$ of IMI, respectively. Only CNS IMI was associated with PMSD. A nonlinear relationship between PMSD and incidence of CNS IMI was found; cows with a PMSD of 90 to 120 min were at a reduced risk for CNS IMI. The risk of experiencing CNS IMI was also reduced with increased frequency of feed push-ups and provision of fresh feed 60 min before to 90 min after milking and >540 min after milking. These results indicate that management practices that promote PMSD of 90 to 120 min, such as the provision of fresh feed or freshly pushed-up feed around the time of milking, providing ample feed bunk space per cow, and keeping freestall stocking density low, should be encouraged to reduce the risk of CNS IMI in freestallhoused cows milked $3 \times / d$.

Key words: mastitis, behavior, dairy cow

\section{INTRODUCTION}

Encouraging cows to remain on their feet after milking has been a long-accepted practice surmised to decrease the incidence of IMI in lactating dairy cows. This practice is thought to increase the likelihood that the teat canals will have closed before the udder contacts the stall substrate when the cow lies down, thus decreasing the odds of bacterial penetration of the teat, and by association resulting in a decreased risk of IMI (Tyler et al., 1997; Johansson et al., 1999). Recent research on the effects of farm management on standing and lying behavior and the incidence of IMI provides some evidence of a relationship between incidence of IMI and postmilking standing duration (PMSD; DeVries et al., 2010, 2011), as described below.

In a recent longitudinal study, decreased odds of environmental IMI in tie-stall-housed cows was observed with PMSD of 40 to $60 \mathrm{~min}$ as compared with those animals lying down within 40 min of milking, whereas the incidence of new environmental IMI increased as PMSD increased past 60 min (DeVries et al., 2010). 
A similar type of study but undertaken with freestall, robotic-milked cows noted that the only IMI pathogens associated with PMSD were CNS (DeVries et al., 2011). In that study, the incidence of new CNS IMI was similar in cows with PMSD of up to $2.5 \mathrm{~h}$, after which the risk tended to increase (DeVries et al., 2011). Interestingly, few of the robotic-milked cows laid down soon after milking, which DeVries et al. (2011) hypothesized may have contributed to a lack of an increased risk observed in the time period immediately following milking when risk has traditionally thought to be greatest.

Given the tremendous variation in management of freestall-housed dairy cows observed on commercial farms (von Keyserlingk et al., 2012), it follows that IMI risk and PMSD may be affected by differences in management that in turn affect lying behavior. DeVries et al. (2010) reported a mean PMSD of 79 min for tie-stall-housed cows. This value was comparable to subsequent studies observing cows under freestall housing conditions milked by an automatic milking system (AMS; 78 min, DeVries et al., 2011; 77 min, DeVries et al., 2012). However, a shorter PMSD was reported by Tyler et al. (1997) when observing the effects of feed provision following milking on freestall-housed cows milked $2 \times / \mathrm{d}$ in a parlor: $48 \mathrm{~min}$ for cows with access to feed versus $21 \mathrm{~min}$ for cows without access to feed. This reduced latency to lie down after milking in $2 \times / \mathrm{d}-$ milked freestall cows as a response to fresh feed access was also found by DeVries and von Keyserlingk (2005); cows provided with fresh feed had an average PMSD of $66 \mathrm{~min}$ versus $45 \mathrm{~min}$ for cows without access to fresh feed. Also under freestall housing and $2 \times /$ d milking, Fregonesi et al. (2007) observed an average PMSD of 39 min under 100\% stocking conditions.

It is plausible that the reduced latency to lie observed in freestall $2 \times / \mathrm{d}$ parlor milking conditions is a result of the forced period of standing inherent to parlor milking practices. Thus, this period of forced standing may be expected to affect PMSD in herds milked $3 \times / \mathrm{d}$, as well. A study of 16 freestall herds, milking either 2 or $3 \times / d$, revealed that mean daily milking time was $2.7 \mathrm{~h} / \mathrm{d}$ with a range of 0.5 to $6 \mathrm{~h} / \mathrm{d}$ on the $2 \times / \mathrm{d}$ milking farms and a range of 1.2 to $5.7 \mathrm{~h} / \mathrm{d}$ on the $3 \times / \mathrm{d}$ milking farms (Gomez and Cook, 2010). In a study of North American freestall herds, mean time away from pen was reported as almost $4 \mathrm{~h} / \mathrm{d}$ in Western herds and almost $5 \mathrm{~h} / \mathrm{d}$ in Eastern herds, indicating that regardless of milking frequency, parlor-milked cows experience long periods of time outside of their pens (von Keyserlingk et al., 2012). Although long group milking times have been reported, individual variability in milking time exists; Cook and Nordlund (2009) noted that although parlor design and group sizes generally target a milking time of 45 to 60 min per group, individual cow daily milking times may be quite variable ranging from $1.5 \mathrm{~h} / \mathrm{d}$ to more than $3 \mathrm{~h} / \mathrm{d}$ in $3 \times / \mathrm{d}$-milked cows. Thus, reduced PMSD may be anticipated in cows milked $3 \times /$ d given the increased potential for standing demands associated with this management practice and the expectation that cows will choose to lie down more quickly following milking if not provided with an incentive to remain standing, such as fresh feed.

The objectives of this study were, for freestall cows milked $3 \times / \mathrm{d}$, to determine (1) which factors are associated with PMSD and (2) whether an association of PMSD with incidence of IMI exists. It was hypothesized that cows that had shorter PMSD would be at an increased risk to experience an IMI and that PMSD would be longer when feed delivery and feed push-up occurred close to the time of milking.

\section{MATERIALS AND METHODS}

\section{Farm Selection}

Four commercial dairy farms in Eastern Ontario, Canada, were recruited for participation in this longitudinal study. Herds were selected as a convenience sample for their proximity to the University of Guelph, Kemptville Campus (Kemptville, ON, Canada). Selection criteria were as follows: freestall housing, parlor milking, milked $3 \times / \mathrm{d}$, participated in a DHI program, predominantly Holstein-Friesian (>90\%), >120 lactating cows in the herd, and no sand bedding. Farms had a mean herd size of 326 cows (range: 133 to 566 cows), mean adjusted 305-d milk yield of $11,670 \mathrm{~kg}$ (range: 10,801 to $13,012 \mathrm{~kg}$ ), and a geometric mean annual bulk milk SCC of 240,000 cells/mL (range: 161,000 to 330,000 cells $/ \mathrm{mL}$ ). The study was conducted between April and August 2012. Initiation of the study on each farm was based on a rolling start date corresponding to the DHI test dates of each farm. The study was composed of three 28-d periods beginning on the initial on-farm milk-sample date. Use of animals for this study was approved by the University of Guelph's Animal Care Committee (Animal Use Protocol \#1665).

\section{Animal Selection}

Forty cows per herd were randomly selected as focal animals from those cows on each farm that met our selection criteria of $<200$ DIM and SCC $<100,000$ cells/ $\mathrm{mL}$ at the most recent DHI test. Less than 200 DIM was targeted to ensure that focal cows would remain in the milking herd for at least 2 periods of the study. An SCC of $<100,000$ cells $/ \mathrm{mL}$ was targeted as a prescreening method for IMI, and these cows were assumed to be infection free (Dohoo and Leslie, 1991; Schepers et 
al., 1997; Schukken et al., 2003); bacteriological culture of quarter milk samples later confirmed the IMI status of all focal cows at the start of the study. Lactation number and DIM were recorded from farm records for each focal cow and validated using DHI data.

\section{Milk Sampling}

The study began following a regularly scheduled DHI milk test to allow for selection of focal animals based on SCC. All focal cows enrolled in the study were subjected to an initial quarter aseptically milk sampling regimen (Hogan et al., 1999) undertaken by 2 trained personnel. This initial sample served as a baseline sample to determine whether a cow was truly culture negative and to allow for determination of new instances of infection in subsequent periods of the study.

Milk samples were then collected on a 28-d cycle, not necessarily concurrent with a DHI test date, for a total of 4 sets of milk samples taken from each focal cow on each farm beginning with the initial baseline sample. All milk sampling was done at the second daily milking on each farm. Cows entered the parlor and were prepped by the farm milking personnel according to their normal milking procedures (predip, fore-stripping, and so on). Immediately following, researchers disinfected teat ends with cotton swabs soaked in $70 \%$ alcohol and allowed teats to dry. A 30-mL milk sample was then drawn into a labeled sterile container for each quarter (DeVries et al., 2010; DeVries et al., 2011). In collecting a 30-mL aseptic sample our intent was to complete both bacteriology and SCC on the quarter-level samples. However, study limitations led to the SCC measurement being abandoned, although the original milk sample size was maintained throughout the course of the study for consistency. As noted by Reyher et al. (2011), aseptic collection of a $30-\mathrm{mL}$ sample has its inherent challenges given the movement of cows and the sanitary conditions of the parlor setting at collection time. However, a single sample for bacteriology and SCC analysis limited the likelihood of logistical issues compromising the collected samples. Therefore, the collection of a $30-\mathrm{mL}$ sample was determined to be necessary before the start of this study. Following sample collection, the milking unit was then placed on the cow and normal milking procedures proceeded. All milk samples were stored at $-20^{\circ} \mathrm{C}$ before being shipped for bacteriological analysis (DeVries et al., 2010; DeVries et al., 2011).

\section{Milk-Sample Analysis}

Samples were shipped overnight to the University of Calgary, Faculty of Veterinary Medicine (Calgary, $\mathrm{AB}$, Canada), for milk bacteriological culture. The bacteriological culturing protocol and pathogen species identification followed the National Mastitis Council guidelines (Harmon et al., 1990; Pankey et al., 1991; Woolford et al., 1998; NMC, 2004). Briefly, blood agar plates were segregated into 4 sections with each zone representing one quarter. An inoculum of $10 \mu \mathrm{L}$ of milk was then spread over each respective section using a sterile $10-\mu \mathrm{L}$ inoculating loop following agitation of the 30 -mL sample. All plates were then incubated at $37^{\circ} \mathrm{C}$ and examined for bacterial growth at 24 and $48 \mathrm{~h}$. Following $48 \mathrm{~h}$ of incubation, colonies were enumerated and speciated. Subculturing of colonies was performed where necessary to ensure sufficient sample for further tests to determine pathogen type.

Samples that were culture positive for 3 or more pathogens, except for those that included Staphylococcus aureus or Streptococcus agalactiae, were classified as contaminated and no longer considered for further analysis (Sampimon et al., 2009; DeVries et al., 2011). A milk sample was considered culture positive when $\geq 100 \mathrm{cfu} / \mathrm{mL}$ of a major pathogen (i.e., Staph. aureus, Strep. agalactiae, Streptococcus uberis, Streptococcus dysgalactiae, Escherichia coli, Enterobacter spp., Klebsiella spp.) or $\geq 500 \mathrm{cfu} / \mathrm{mL}$ of a minor pathogen (i.e., CNS, Corynebacterium spp., Trueperella pyogenes, Staphylococcus hyicus, Enterococcus spp., Streptococcus spp., Nocardia spp.) was cultured (Sampimon et al., 2009). Given the preliminary nature of this study, we did not speciate CNS species. Mycoplasma spp. milkculture procedures were not conducted in this study.

Intramammary infections were identified at the quarter level (Harmon et al., 1990). The occurrence of a new IMI was considered when a culture-positive sample of the specific pathogen was preceded by a culture-negative sample collected during the previous milk sampling. Animals were only considered to be at risk for a new IMI if they were culture negative for that specific pathogen at the previous testing. Nonoccurrence of a new IMI was defined as 2 consecutive culture-negative samples for the specific pathogen. To be considered at risk for a new IMI during the second, third, or fourth milk sampling, a quarter would have to have been culture negative during the first, second, or third milk sampling, respectively. Based on these definitions, a cow could only experience a maximum of 2 new IMI for each pathogen throughout the study duration. Quarter-level milk samples were not collected from cows that were treated for a known IMI during that sampling period.

\section{Standing and Lying Behavior}

Standing and lying behaviors were recorded using data loggers (HOBO Pendant G Data Logger, Onset 
Computer Corporation, Pocasset, MA). These devices allowed standing and lying behavior to be electronically recorded by measuring leg orientation in 1-min intervals with a validated sensitivity and specificity $>99 \%$ to accurately record lying behaviors (Ledgerwood et al., 2010). Data loggers were affixed to the rear metatarsal area of the focal cows with veterinary bandaging tape (Vetrap Bandaging Tape, 3M, London, ON, Canada) for the first $5 \mathrm{~d}$ of each period following the first 3 milk samplings. Recorded data were monitored for abnormalities that may indicate data logger malfunction, and data loggers were routinely checked to ensure proper performance. Ito et al. (2009) and Vasseur et al. (2012) demonstrated that recording lying behavior for 3 and $4 \mathrm{~d}$, respectively, produced an accurate result of herd-level lying behavior using the same technology used in this study. By using $5 \mathrm{~d}$ of recording, we sought to improve the accuracy of our results and increase the likelihood that we were recording the normal (typical) behavior of a cow.

Lying behavior was recorded at the start of each period to determine lying times when they were culture negative; this behavior was then related to future risk for acquiring a new IMI (Medrano-Galarza et al., 2012). The lying behavior of culture-positive cows was not considered in the risk-factor analysis. Standing and lying duration (min/d), lying bout frequency (no./d), and lying bout duration ( $\mathrm{min} /$ bout) were calculated using the recorded data. Standing and lying duration, as well as lying bout frequency, were derived from the logger data using protocols described by Ledgerwood et al. (2010); average daily lying bout duration was determined by dividing the daily lying duration by the number of lying bouts. Premilking standing duration (min) was defined as the interval between initiation of milking and the last observation of lying before milking. Postmilking standing duration (min) was defined as the interval between the initiation of milking and the initial observation of lying following milking.

\section{Cow Measures}

Individual milking times and milk production for each focal cow were obtained from parlor records. Focal cows were hygiene scored (Cook and Reinemann, 2007) and locomotion scored (Flower and Weary, 2006) simultaneously by 2 trained observers, who were blind to each other's scores, for all 3 periods at the conclusion of each 5-d recording period. Given that the focal cows were randomly distributed throughout the herd, the herd manager recorded feed delivery and feed push-up times for each milking group that contained focal cows. The interval between all feed manipulation events, including fresh feed delivery, feed push-up, and milking time, was calculated for each focal cow by determining the time (in min) between the individual milking time of each focal cow and the feed manipulation event that took place closest to the time of that milking.

\section{Herd, Housing, and Management Data}

Before the commencement of the study, a questionnaire, adapted from Dufour et al. (2010, 2011), was distributed and completed by the owner or herd manager. In addition to the written survey, these individuals were questioned by a single interviewer on the general housing and management present on each farm, including milking practices, stall dimensions, bedding (type, quantity, frequency of cleaning), and management style. Although all farms fed a TMR to their lactating cows, bedding, stall design, feeding regimen (including feed delivery and feed push-ups), and cleaning systems varied by farm. A description of farm-level variables can be found in Table 1. Fresh feed delivery, feed pushup frequency, freestall stocking density, feed bunk space per cow, stall base, bedding type, and encouraging cows to remain standing postmilking were all considered as farm-level variables for the statistical analysis. All farms used automatic alley scrapers to clean passageways (one farm also had slatted floors on one passage), and all farms had parallel milking parlors. Daily milking times were variable across all farms; however, all farms maintained an 8-h interval between milkings. Cows entered a holding pen before milking on all farms, and farms grouped lactating cows based on production, parity, or both. All milking units had automatic takeoff, and none of the farms cleaned the units between cows; some farms rinsed the units with a spray of water following a bucket cow (a fresh or treated cow depending on the practices of the particular farm) or between milking groups after the equipment had been soiled.

\section{Statistical Analysis}

Before analyses, all data were screened for normality using the UNIVARIATE procedure of SAS (SAS Institute Inc., 2011). Cow baseline SCC and PMSD were slightly right skewed and, thus, transformed by the natural logarithm. All cow-level data were summarized across each of the 5-d observation periods for each cow. The associations between PMSD (for each milking of the day) and possible cow-level and herdlevel explanatory (independent) fixed-effect variables were analyzed with multivariable linear mixed models using the MIXED procedure of SAS, treating period as a repeated measure. The models included the random effects of herd and cow within herd. Variables unique to a herd (Table 1) were not included in the models 
Table 1. Descriptive summary of farm-level variables included in statistical analysis

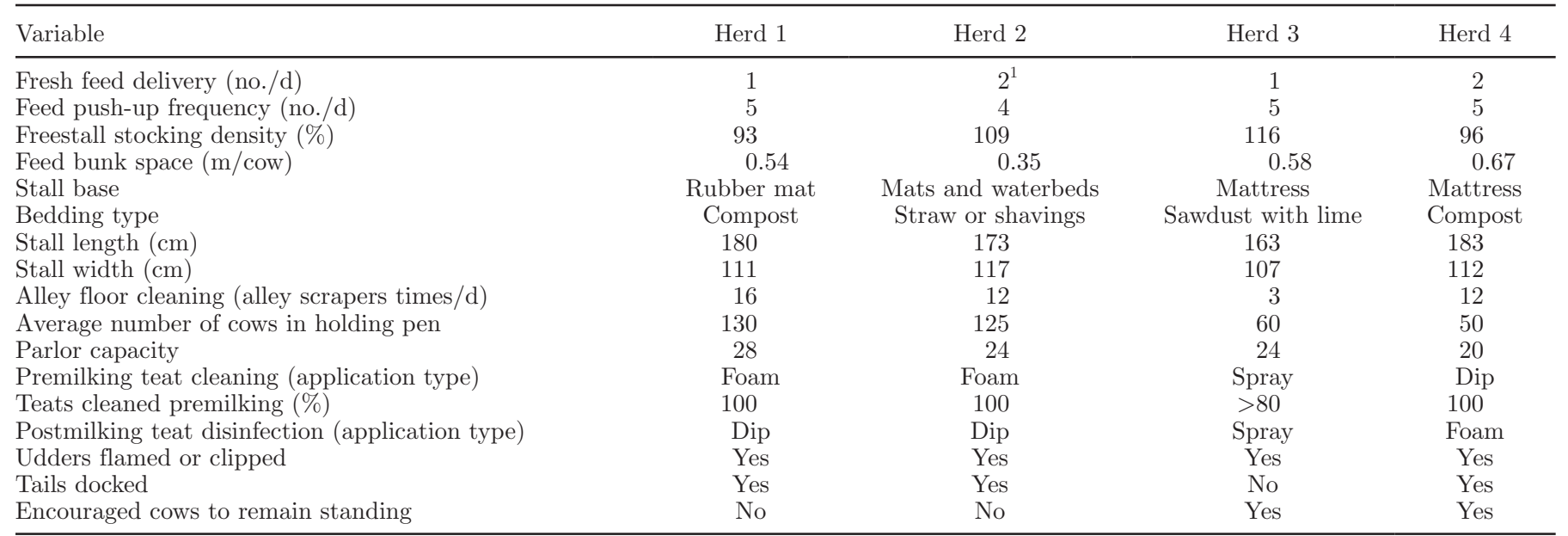

${ }^{1}$ The farmer indicated that they had 2 deliveries of feed per day. The second delivery occurred $1 \mathrm{~h}$ following the morning feeding and acted as a top-up.

because variability associated with these effects is accounted for in the herd effect, which was included in each model. Cow within herd was included in the models as the subject of the repeated statement. Initially, unconditional associations between independent variables and dependent variables were conducted. For variables measured on a continuous scale, linearity of the relationship between the variable and PMSD was assessed by plotting the variable and categorizing it based on the data distribution. As addressed in detail later on, fresh feed delivery delay and feed manipulation delay were categorized a posteriori, given the nonlinear relationship between these 2 variables and PMSD (DeVries et al., 2010, 2011). Average feed manipulation delay (difference in time between individual milking time and closest fresh feed delivery or feed push-up) was categorized as follows: $>60$ min before milking, 60 to 30 min before milking, 30 min before to 60 min after milking, and $>60$ min after milking (Figure 1). Average fresh feed delivery delay (difference in time between individual milking time and closest fresh feed delivery) was categorized as $>300$ min before milking, 300 to 60 min before milking, 60 min before to 90 min after milking, 90 to $180 \mathrm{~min}$ after milking, 180 to $540 \mathrm{~min}$ after milking, and $>540$ min after milking (Figure 2). Only independent variables with $P \leq 0.25$ in this initial screening were included in multivariable linear regression models (Dohoo et al., 2009). The CORR procedure of SAS was used to check for correlations between the kept explanatory variables. If 2 variables were highly correlated $(\mathrm{r}>0.6)$, the one with the lower $P$-value in the unconditional associations was kept. Manual backward elimination of nonsignificant $(P>0.10)$ variables was used and from the resultant models, plausible 2 -way interactions were examined and retained if $P \leq$
0.10. The multivariable model for PMSD indicated a significant interaction between daily milking time (first, second, or third milking of the day) and the fresh feed delivery delay; therefore, separate analyses were done for PMSD for each daily milking. Only those results retained in the final multivariable models are presented. The covariance structure was compound symmetry by best fit according to Schwarz's Bayesian information criterion.

The association of the various cow-level and farmlevel explanatory variables on the occurrence or nonoccurrence of an IMI was analyzed using a random intercept mixed logistic model using the GLIMMIX

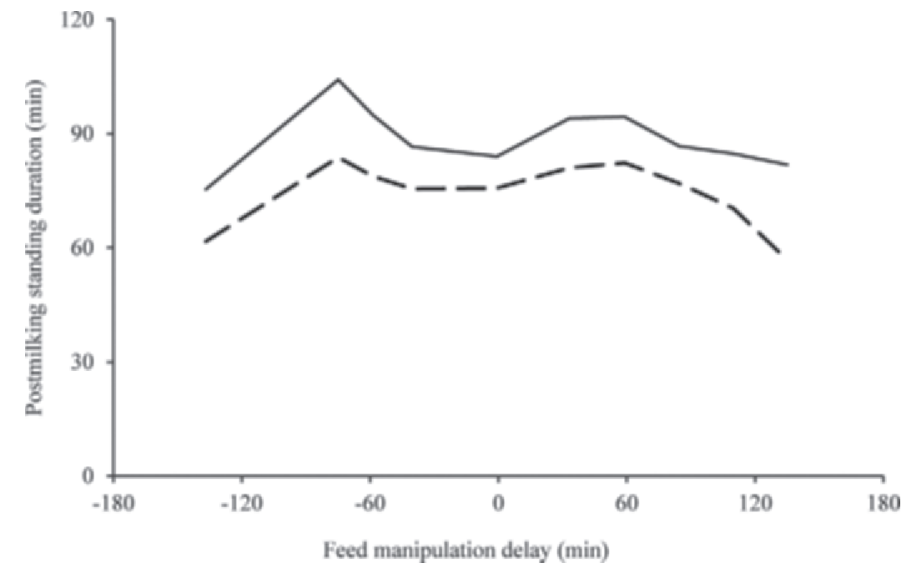

Figure 1. Moving average (with width of $60 \mathrm{~min}$ and increments of increase of $30 \mathrm{~min}$ ) of postmilking standing duration across feed manipulation (fresh feed or feed push-up) delay (mean = solid line; median $=$ dashed line). Negative feed manipulation delay represents feed manipulation before time of milking of individual cow, 0 value corresponds with feed manipulation occurring while individual cow was being milked, and positive values represent feed manipulation occurring following time of milking of individual cow. 


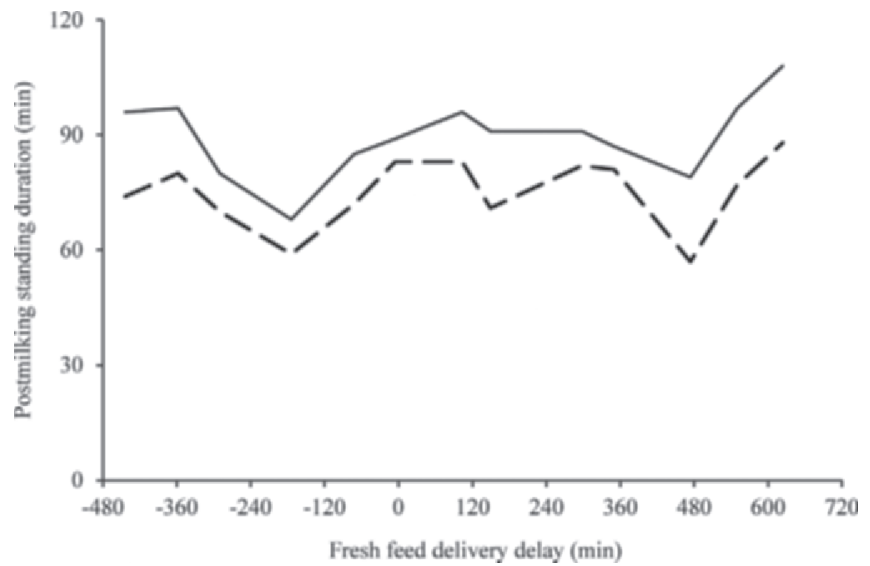

Figure 2. Moving average (with width of $120 \mathrm{~min}$ and increments of increase of $90 \mathrm{~min}$ ) of postmilking standing duration across fresh feed delivery delay $($ mean $=$ solid line; median $=$ dashed line). Negative fresh feed delivery delay represents fresh feed delivery before time of milking of individual cow, 0 value corresponds with feed delivery occurring while individual cow was being milked, and positive values represent feed delivery occurring following time of milking of individual cow.

procedure (distribution $=$ binomial and link $=$ logit $)$ of SAS. As new IMI were assessed at the quarter level, herd, cow within herd, and quarter within cow within herd were considered as random effects to account for potential clustering. Potential effects of clustering were also tested for by including those variables within the model and noting if the outcome changed; testing did not produce an alternate outcome. Thus, these variables were retained in the model as random effects. Unconditional associations were estimated in the described model to screen all potential explanatory variables. For variables measured on a continuous scale, linearity of the relationship between the variable and the occurrence of an IMI was assessed by categorizing the continuous variable and visual inspection of plots of the odds ratio against mean values of the categories. Given the nonlinearity of the relationship between PMSD and risk of a new CNS IMI, meaningful categories of PMSD were chosen a posteriori, based on data distribution and existing knowledge on teat morphology and teat canal closure following milking (McDonald, 1975; Schultze and Bright, 1983). Postmilking standing duration was categorized as follows: $<60 \mathrm{~min}, 60$ to $75 \mathrm{~min}, 75$ to $90 \mathrm{~min}, 90$ to $120 \mathrm{~min}$, and $>120$ min (Figure 3). Variables with $P \leq 0.25$ were submitted to the multivariate model. The CORR procedure of SAS was used to check for correlations between explanatory variables. If 2 variables were highly correlated $(\mathrm{r}>0.6)$, the one with the lower $P_{-}$ value in the unconditional associations was kept. These kept variables were then included in the previously described multivariable analysis. Manual backward elimination of nonsignificant $(P>0.10)$ effects was used, and from the resultant models, plausible 2-way interactions were examined and retained if $P \leq 0.10$. Only those variables retained in the final multivariable logistic regression model are presented.

\section{RESULTS}

Ten cows were eliminated from the study at various points because of drying-off (1), culling (4), illness (1), or death (4). A descriptive summary of focal cow parameters, including parity, DIM, baseline SCC, and 305-d milk production, is presented per farm in Table 2. Table 3 contains a descriptive summary for data on all 160 focal cows collected across the study periods.

\section{Factors Influencing Postmilking Standing Duration}

Average PMSD across all 3 periods of the study was $96 \mathrm{~min}$ (median $=80 \mathrm{~min}$ ). The average feed manipulation delay was $20 \pm 63$ min (mean $\pm \mathrm{SD}$ ) before milking, and the average fresh feed delivery delay was $100 \pm$ 357 min after milking. The relationship between PMSD and feed manipulation was nonlinear. Postmilking standing duration peaked when feed was manipulated around 60 min before milking, and a second incidence of increased PMSD was observed in instances where feed was manipulated between 30 to 60 min following milking (Figure 1). The relationship between PMSD and fresh feed delivery was also nonlinear with PMSD decreasing when fresh feed was delivered 120 to $300 \mathrm{~min}$ before milking and a second lesser decrease of PMSD when fresh feed was delivered between 360 and $600 \mathrm{~min}$ following milking (Figure 2).

Mean PMSD for the first daily milking was $86 \pm$ 54 (mean \pm SD) min. An increase in PMSD following the first daily milking tended to be associated with increased frequency of feed push-ups and was associated with increased bunk space per cow (m/cow; Table 4$)$. Each additional feed push-up per day was associated with a 6 -min increase in PMSD, and every $0.1 \mathrm{~m} /$ cow increase in bunk space was associated with a 19-min increase in PMSD. Increased freestall stocking density (\%) was associated with a decrease in PMSD (Table 4); every $10 \%$ increase in stocking density was associated with a 2 min decrease in PMSD. Manipulation of feed between 60 to 30 min before milking and between 30 min before and $60 \mathrm{~min}$ after milking was associated with an 8 and 5 min, respectively, reduction in PMSD (Table 4). Delivery of fresh feed between 180 and 540 min after milking was associated with a 23 -min decrease in PMSD (Table 4). 
Table 2. Descriptive summary of the focal cows sampled within each study herd at the beginning of the study period

\begin{tabular}{lccccc}
\hline Herd & $\begin{array}{c}\text { Cows } \\
\text { sampled/herd }\end{array}$ & $\begin{array}{c}\text { Mean } \\
\text { parity }\end{array}$ & $\begin{array}{c}\text { Mean } \\
\text { DIM }\end{array}$ & $\begin{array}{c}\text { Geometric mean } \\
\text { baseline SCC } \\
(\times 1,000 \text { cells } / \mathrm{mL})\end{array}$ & $\begin{array}{c}\text { Mean 305-d milk } \\
\text { production }(\mathrm{kg})\end{array}$ \\
\hline 1 & 40 & 2.5 & 71 & 29 & 10,801 \\
2 & 40 & 2.4 & 73 & 33 & 11,298 \\
3 & 40 & 2.3 & 68 & 33 & 11,568 \\
4 & 40 & 1.9 & 109 & 33 & 13,012 \\
Total & 160 & 2.3 & 81 & 32 & 11,670 \\
\hline
\end{tabular}

Mean PMSD following the second daily milking was $99 \pm 71$ min $($ mean \pm SD). Increased PMSD following the second daily milking was associated with increased feed push-ups (Table 4); each additional feed push-up was associated with a 7-min increase in PMSD. Delivery of fresh feed between 90 and 180 min after milking was associated with a 20-min increase in PMSD after the second daily milking (Table 4).

Mean PMSD following the third daily milking was 94 \pm 62 min (mean $\pm \mathrm{SD}$ ). Increased PMSD following the third daily milking was associated with increased feed push-ups (Table 4); each additional feed push-up was associated with a 10-min increase in PMSD. Decreased PMSD was associated with DIM and milk order (Table 4). Later-lactation cows had a reduced PMSD, with PMSD decreasing by $4 \mathrm{~min}$ for every additional 50 DIM. Cows coming later in the milking order also had a decreased PMSD, with PMSD 11 min longer when comparing a cow milked 25th out of 100 cows to one milked 75 th.

\section{Association of PMSD and Incidence of IMI}

A total of 2,460 milk samples were collected over the course of the study. Twenty-eight (1.1\%) of the samples were identified as being contaminated. Overall, across the three 28-d observation periods, 1,846 quarters were considered at risk for a new IMI. A total of 456 new IMI were detected throughout the study for an incidence rate of 3.22 IMI per quarter year. Coagulase-negative staphylococci and Corynebacterium spp. were the most commonly observed organisms cultured causing 45 and $31 \%$, respectively, of the total culture-positive results. Other pathogens responsible for new IMI were

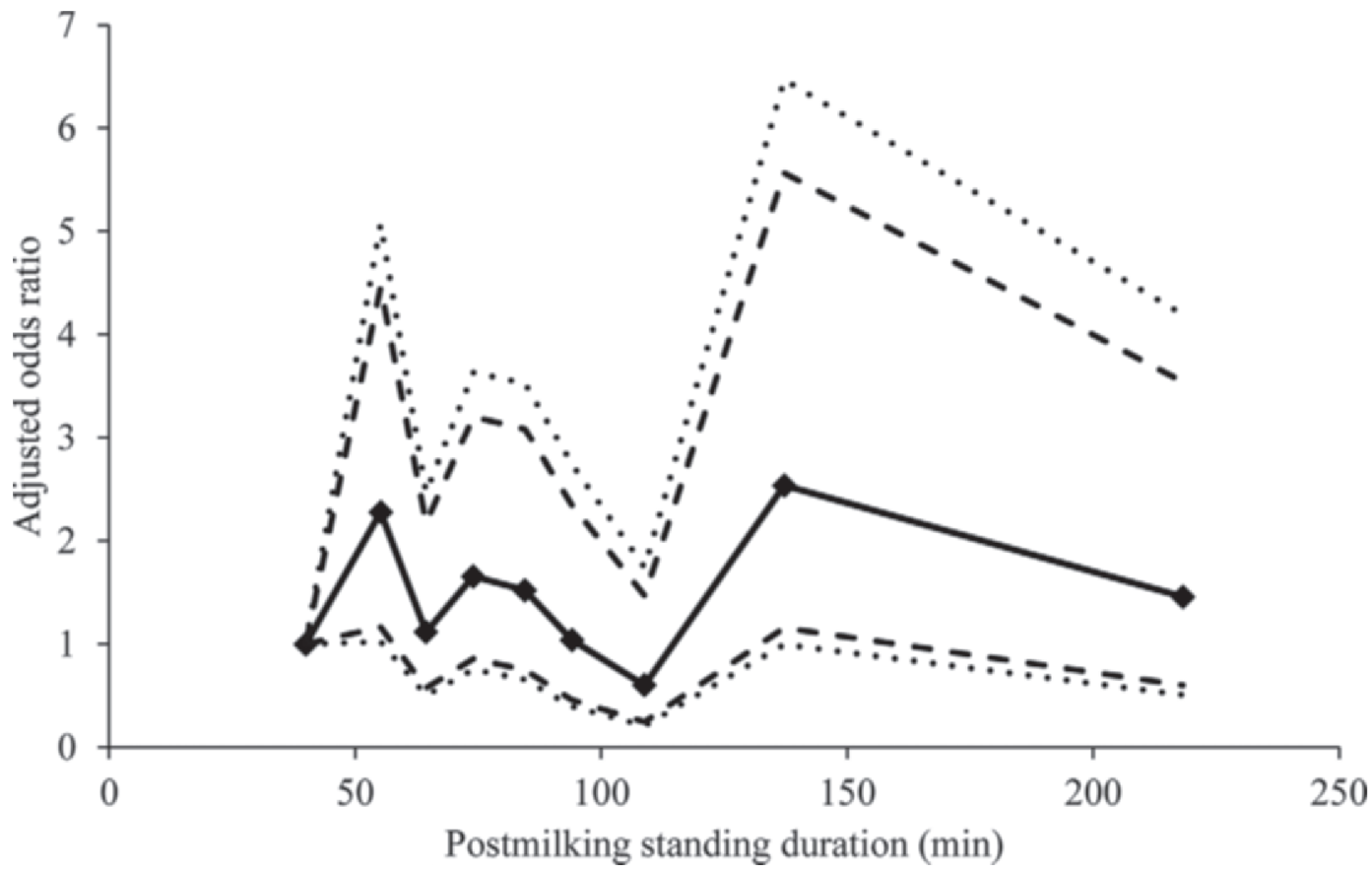

Figure 3. Adjusted estimates of the odds of acquiring a new CNS IMI across deciles of average postmilking standing duration (solid line) with $90 \%$ (dashed lines) and $95 \%$ (dotted lines) confidence limits. Data are averaged by period for each of the 160 focal cows (40 from each of 4 herds). 
Table 3. Descriptive summary of data from focal cows $(n=160)$ across all 4 study herds ${ }^{1}$

\begin{tabular}{lcccc}
\hline Variable & Mean & SD & Minimum & Maximum \\
\hline DIM $^{2}$ & 80 & 43 & 15 & $209^{3}$ \\
Parity $_{\text {SCC }}(\times 1,000$ cells/mL) & 2.3 & 1.2 & 1 & 9 \\
Milk yield (kg/d) & 32 & 21.3 & 10 & 66 \\
Lying time (h/d) & 41 & 8.5 & 20 & 17 \\
Lying bouts (no./d) & 10 & 2.2 & 2.2 & 27 \\
Lying bout duration (min/bout) & 9 & 3.1 & 2 & 169 \\
Postmilking standing time (min) & 73 & 22.2 & 22 & 371 \\
Premilking standing time (min) & 96 & 52 & 20 & 5 \\
Lameness score $^{4}$ & 106 & 64 & 20 & 4 \\
Hygiene score & 1.6 & 0.8 & 1 & 4 \\
$\quad$ Udder & & & & 4 \\
Upper leg or flank & 2.3 & 0.6 & 1 & 4 \\
Lower legs & 2.4 & 0.6 & 1 & 2.5 \\
\hline
\end{tabular}

${ }^{1}$ Data averaged across all 3 study periods for all of the 160 focal cows from each of the 4 herds.

${ }^{2}$ Baseline data collected at beginning of study.

${ }^{3}$ One cow > 200 DIM was used because of low selection availability on one farm.

${ }^{4}$ Gait score was assessed on a 5 -point scale $(1=$ normal to $5=$ severely lame; Flower and Weary, 2006; Ito et al., 2009). Lameness was dichotomized for analysis into not lame $=$ gait score $<3$, lame $=$ gait score $\geq 3$. Throughout the study $12.4 \%$ of focal cows were categorized as lame.

${ }^{5}$ Hygiene score was assessed on a 4 -point scale $(1$ = very clean to 4 = very dirty; www.vetmed.wisc.edu/dms/ fapm/fapmtools/4hygiene/hygiene.pdf; Cook and Reinemann, 2007).

46 Streptococcus spp., 40 Enterococcus spp., 10 Staph. hyicus, 8 T. pyogenes, 3 Staph. aureus, 2 Strep. dysgalactiae, 1 E. coli, 1 Enterobacter spp., 1 Nocardia spp., 1 Strep. agalactiae, and 1 Strep. uberis. A total of 202 new CNS IMI were detected for an incidence rate of 1.62 CNS IMI per quarter year, and a total of 140

Table 4. Final general linear model for those factors significantly associated with postmilking standing duration

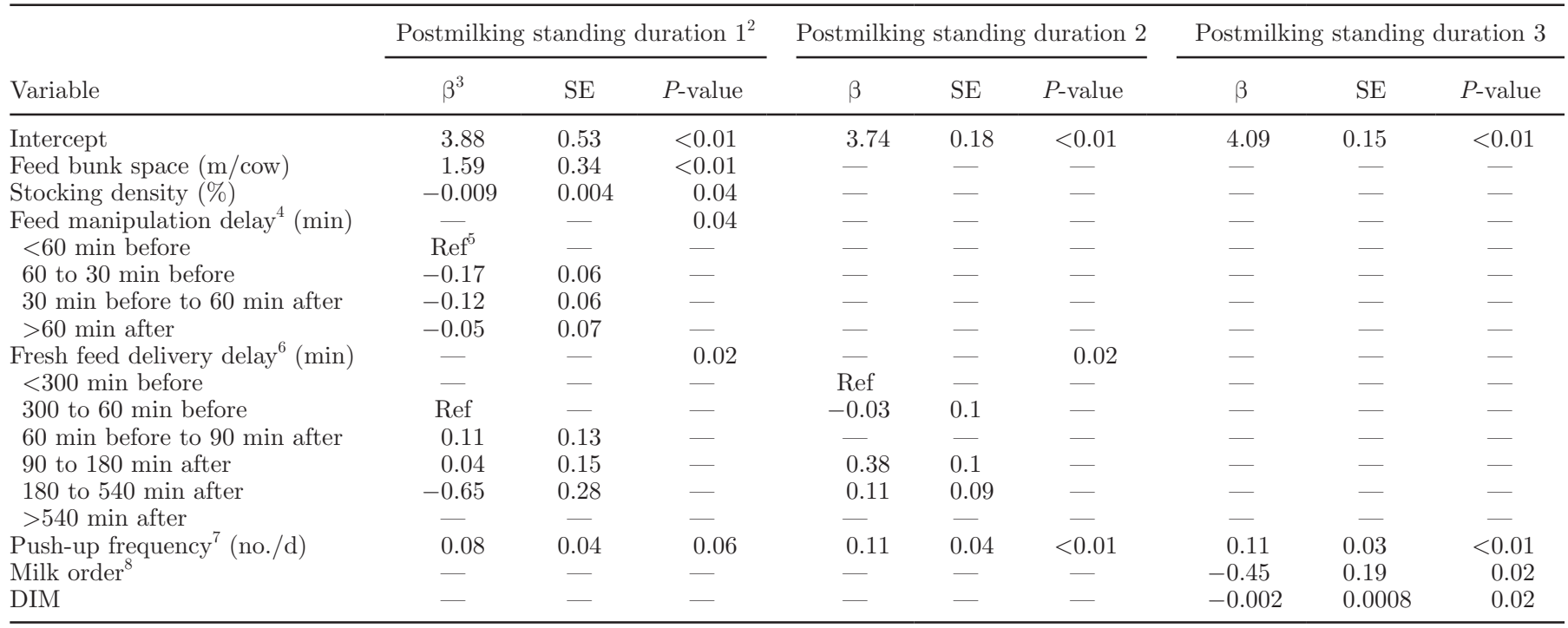

${ }^{1}$ Data averaged by period for all 160 focal cows (40 from each of the 4 herds) that were observed for $5 \mathrm{~d}$ for each period

${ }^{2}$ Postmilking standing duration associated with each individual milking time (1 denotes first milking of the day and so on).

${ }^{3} \beta=$ estimated regression coefficient.

${ }^{4}$ Feed manipulation delay $=$ difference in time between individual milking time and closest feed manipulation (fresh feed delivery or feed pushup).

${ }^{5}$ Ref $=$ reference category.

${ }^{6}$ Fresh feed delivery delay $=$ difference in time between individual milking time and closest fresh feed delivery.

${ }^{7}$ Push-up frequency $=$ number of feed push-ups per day.

${ }^{8}$ Milk order $=$ point at which the individual cow was milked within the overall order (tested as an index with individual milking of a cow/overall number of cows milked). 
Table 5. Number of quarter milk samples taken per farm and number of new IMI across the study period ${ }^{1}$

\begin{tabular}{|c|c|c|c|c|c|c|c|c|}
\hline Herd & $\begin{array}{l}\text { Total } \\
\text { samples }\end{array}$ & $\begin{array}{l}\text { Total } \\
\text { quarters } \\
\text { at risk }^{3}\end{array}$ & $\begin{array}{l}\text { No. of } \\
\text { new } \mathrm{IMI}^{4}\end{array}$ & $\begin{array}{c}\text { IMI } \\
\text { incidence rate } \\
\text { (IMI/quarter year) }\end{array}$ & $\begin{array}{l}\text { No. of new } \\
\text { CNS IMI }\end{array}$ & $\begin{array}{c}\text { CNS IMI } \\
\text { incidence rate } \\
\text { (IMI/quarter year) }\end{array}$ & $\begin{array}{l}\text { No. of new } \\
\text { Corynebacterium spp. IMI }{ }^{3}\end{array}$ & $\begin{array}{c}\text { Corynebacterium spp. IMI } \\
\text { incidence rate } \\
\text { (IMI/quarter year) }\end{array}$ \\
\hline 1 & 610 & 467 & 124 & 3.46 & 42 & 1.32 & 54 & 1.78 \\
\hline 3 & 611 & 457 & 64 & 1.83 & 14 & 0.42 & 28 & 0.85 \\
\hline 4 & 627 & 472 & 94 & 2.60 & 69 & 2.29 & 19 & 0.56 \\
\hline Total & 2,460 & 1,846 & 456 & 3.22 & 202 & 1.62 & 140 & 1.10 \\
\hline
\end{tabular}

${ }^{1}$ Data averaged across all 3 study periods for all of the 160 focal cows from each of the 4 herds.

${ }^{2}$ Total number of samples taken throughout the study across all 4 milk sampling collection dates.

${ }^{3}$ Number of quarters at risk from all 160 focal cows across all 4 milk sampling collection dates. Quarters were considered at risk when the milk sample was analyzed as culture negative at the beginning of each observation period.

${ }^{4}$ New IMI was defined as a culture-positive quarter milk sample for a specific pathogen at the end of each period when the quarter milk sample was culture negative for that specific pathogen at the beginning of each period.

new Corynebacterium spp. IMI were detected for an incidence rate of 1.10 Corynebacterium spp. IMI per quarter year. A complete description of the total IMI, CNS IMI, and Corynebacterium spp. IMI by herd can be found in Table 5. As CNS and Corynebacterium spp. were the organisms responsible for the most culturepositive results (45 and $31 \%$ of new IMI, respectively), the analyses were focused on these 2 specific organisms.

Separate analyses of CNS and Corynebacterium spp. IMI revealed that only CNS IMI risk was associated with PMSD. Therefore, only the results of the CNS IMI analysis are presented below. The relationship between incidence of CNS IMI and PMSD was nonlinear, with an increase in incidence rate for cows standing between 0 and 50 min after milking. After 50 min postmilking, a decline in IMI incidence was observed until approximately $100 \mathrm{~min}$ postmilking, before the incidence of CNS IMI increased again (Figure 4). A second decrease in incidence of CNS IMI was observed when PMSD was $>180$ min. The relationship between PMSD and risk of a new CNS IMI was nonlinear with a pronounced decrease in odds of CNS IMI with a PMSD of $100 \mathrm{~min}$ (Figure 3). Table 6 shows the unconditional associations for CNS IMI of the independent variables from the univariable analyses before running the multivariable analysis. Increased risk of CNS IMI was associated

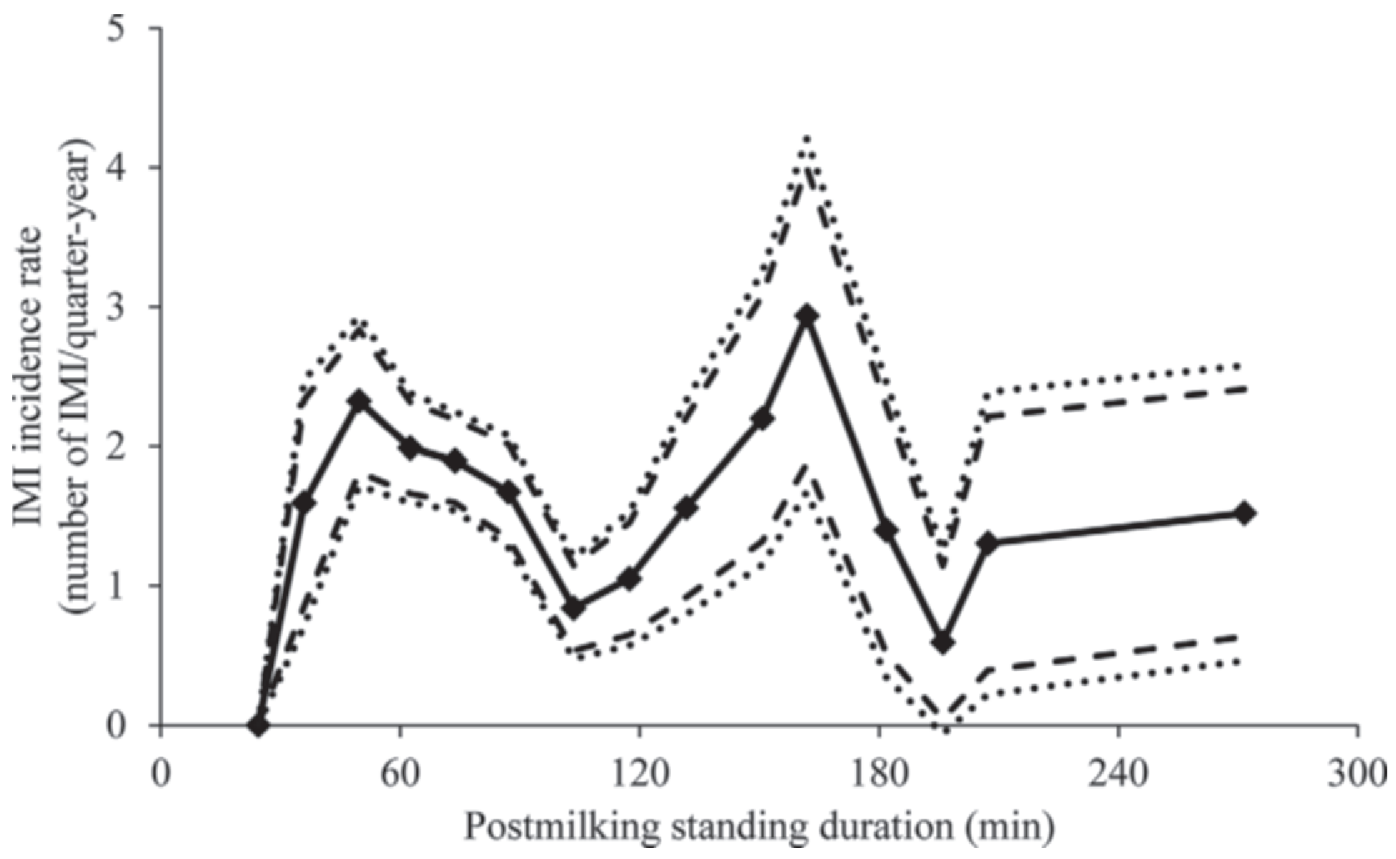

Figure 4. Moving average (with width of $30 \mathrm{~min}$ and increments of $15 \mathrm{~min}$ ) of incidence rate of CNS IMI across average postmilking standing duration (solid line) with $90 \%$ (dashed lines) and $95 \%$ (dotted line) confidence limits. Data are averaged by period for each of the 160 focal cows (40 from each of 4 herds). 
with increased fresh feed delivery frequency, DIM, and delivery of fresh feed between 180 and $540 \mathrm{~min}$ after milking. Decreased risk of CNS IMI was associated with increased frequency of feed push-ups, increased premilking standing time, a PMSD of 90 to $120 \mathrm{~min}$, and delivery of fresh feed between 60 min before and 90 min after milking and $>540$ min after milking. Three of these variables were retained in the final multivariable model (Table 7). Decreased risk of CNS IMI was associated with a PMSD of 90 to $120 \mathrm{~min}$, fresh feed being delivered between 60 min before and 90 min after milking and >540 min after milking, and increased frequency of feed push-ups.

\section{DISCUSSION}

The study median PMSD, $80 \mathrm{~min}$, is much longer than that previously reported in freestall herds parlor milking $2 \times / \mathrm{d}$ (35 min: Tyler et al., 1997; $39 \mathrm{~min}$ : Fregonesi et al., 2007; 55 min: DeVries and von Keyserlingk, 2005; 62 min: DeVries et al., 2005). Postmilking standing duration was more comparable with that reported under tie-stall (79 min: DeVries et al., 2010) and freestall AMS (78 min: DeVries et al., 2011; 77 min: DeVries et al., 2012; 75 min: Deming et al., 2013) conditions. Although PMSD was longer than that reported by other studies on freestall herds, our recording duration and method was selected to increase the likelihood of accurate recording of lying behaviors. Recording for $5 \mathrm{~d}$ was completed to reduce the likelihood of reporting abnormal behavior as a data logger malfunction would be more easily detected over a longer recording period. However, if the data loggers failed to have 100\% specificity or sensitivity to lying behavior, this could potentially skew our interpretation of lying behavior and affect associated outcomes. Specifically, a decrease in sensitivity might result in a higher number of false negatives or more cows being identified as standing when they were in fact lying. The opposing effect would be anticipated with a decrease in specificity whereby more cows may be identified by the data loggers as lying down when in fact they were standing. A reduction in specificity would have a greater effect on misclassification of results than sensitivity; thus, if the specificity of the loggers in this study was less than $100 \%$, we may be underestimating PMSD and overestimating lying events and, as a result, subsequent interpretations with IMI. Therefore, future recommendations would be to include video monitoring to verify accuracy of results where possible.

One would anticipate a shorter PMSD under $3 \times / \mathrm{d}$ milking conditions given that cows would be assumed

Table 6. Unconditional estimates for factors associated with the incidence of CNS IMI ${ }^{1}$

\begin{tabular}{|c|c|c|c|}
\hline Variable & Mean $( \pm \mathrm{SD})$ & $\begin{array}{c}\text { Odds ratio } \\
(95 \% \mathrm{CI})\end{array}$ & $P$-value \\
\hline Feeding frequency ${ }^{2}$ (no./d) & $1.5(0.5)$ & $1.92(1.04,3.55)^{3}$ & 0.04 \\
\hline Push-up frequency ${ }^{4}$ (no./d) & $4.5(0.5)$ & $0.52(0.28,0.96)^{3}$ & 0.04 \\
\hline Premilking standing ${ }^{5}$ (min) & $105.7(61.36)$ & $0.87(0.72,1.07)^{3}$ & 0.19 \\
\hline Fresh feed delivery delay ${ }^{6}(\mathrm{~min})$ & & & $<0.01$ \\
\hline$<300$ min before & - & - & - \\
\hline 300 to $60 \mathrm{~min}$ before & $-81.1(14.02)$ & $\operatorname{Ref}^{7}$ & - \\
\hline $60 \mathrm{~min}$ before to $90 \mathrm{~min}$ after & $39.1(38.23)$ & $0.51(0.28,0.94)^{\mathrm{b}}$ & - \\
\hline 90 to $180 \mathrm{~min}$ after & $129.5(26.51)$ & $0.69(0.36,1.33)^{\mathrm{a}}$ & - \\
\hline 180 to 540 min after & $206.9(17.94)$ & $2.75(1.07,7.06)^{\mathrm{b}}$ & - \\
\hline$>540$ min after & $637.0(13.48)$ & $0.35(0.14,0.87)^{\mathrm{b}}$ & - \\
\hline Postmilking standing duration (min) & & & 0.06 \\
\hline$<60 \min$ & $47.6(9.76)$ & Ref & - \\
\hline $60-75 \min$ & $67.5(4.34)$ & $0.74(0.44,1.24)^{\mathrm{a}}$ & - \\
\hline $75-90 \min$ & $81.5(4.54)$ & $0.83(0.48,1.43)^{\mathrm{a}}$ & - \\
\hline $90-120 \mathrm{~min}$ & $103.5(8.56)$ & $0.39(0.21,0.73)^{\mathrm{b}}$ & - \\
\hline$>120 \min$ & $178.7(55.74)$ & $0.73(0.42,1.28)^{\mathrm{a}}$ & - \\
\hline DIM & $106.7(48.43)$ & $1.25(1.02,1.54)^{3}$ & 0.03 \\
\hline
\end{tabular}

${ }^{\mathrm{a}, \mathrm{b}}$ For comparison with reference category, categories with superscript a were not different and those with superscript b were statistically different.

${ }^{1}$ Data averaged by period for all 160 focal cows (40 from each of the 4 herds) that were observed for $5 \mathrm{~d}$ for each period.

${ }^{2}$ Feeding frequency $=$ the number of fresh feed deliveries per day.

${ }^{3}$ Odds ratio and $95 \%$ CI for $1 \mathrm{SD}$ in variable presented.

${ }^{4}$ Push-up frequency $=$ number of feed push-ups per day.

${ }^{5}$ Premilking standing $=$ the length of time $(\mathrm{min})$ between the attachment of the milking unit and the previous recorded lying bout.

${ }^{6}$ Fresh feed delivery delay $=$ difference in time between individual milking time and closest fresh feed delivery.

${ }^{7}$ Ref $=$ reference category 
Table 7. Final logistic regression model for those factors significantly associated with the incidence of CNS $\mathrm{IMI}^{1}$

\begin{tabular}{|c|c|c|c|c|}
\hline Variable & Coefficient & $\mathrm{SE}$ & $\begin{array}{c}\text { Odds ratio } \\
(95 \% \text { CI })\end{array}$ & $P$-value \\
\hline Intercept & 4.19 & 3.11 & - & 0.31 \\
\hline Random effect & & & & - \\
\hline Herd-level variance & 0.78 & 0.71 & - & - \\
\hline Cow-level variance & 0.78 & 0.22 & - & - \\
\hline Postmilking standing duration (min) & & & & 0.08 \\
\hline$<60 \mathrm{~min}$ & $\operatorname{Ref}^{2}$ & - & - & - \\
\hline $60-75 \min$ & -0.26 & 0.27 & $0.77(0.45,1.32)^{\mathrm{a}}$ & - \\
\hline $75-90 \mathrm{~min}$ & -0.04 & 0.29 & $0.96(0.54,1.69)^{\mathrm{a}}$ & - \\
\hline $90-120 \mathrm{~min}$ & -0.75 & 0.34 & $0.47(0.24,0.92)^{\mathrm{b}}$ & - \\
\hline$>120 \min$ & 0.11 & 0.31 & $1.12(0.60,2.06)^{\mathrm{a}}$ & - \\
\hline Fresh feed delivery delay ${ }^{3}$ (min) & & & & $<0.01$ \\
\hline$<300$ min before & - & - & - & - \\
\hline 300 to $60 \mathrm{~min}$ before & Ref & - & - & - \\
\hline $60 \mathrm{~min}$ before to $90 \mathrm{~min}$ after & -0.66 & 0.31 & $0.52(0.28,0.95)^{\mathrm{b}}$ & - \\
\hline 90 to $180 \mathrm{~min}$ after & -0.39 & 0.34 & $0.68(0.35,1.31)^{\mathrm{a}}$ & - \\
\hline 180 to 540 min after & 0.92 & 0.49 & $2.50(0.96,6.51)^{\mathrm{a}}$ & - \\
\hline$>540$ min after & -1.25 & 0.48 & $0.29(0.11,0.73)^{\mathrm{b}}$ & - \\
\hline Push-up frequency ${ }^{4}$ (no./d) & -1.26 & 0.69 & $0.28(0.07,1.09)^{5}$ & 0.07 \\
\hline
\end{tabular}

${ }_{\mathrm{a}, \mathrm{b}}$ For comparison with reference category, categories with superscript a were not different and those with superscript b were statistically different.

${ }^{1}$ Data averaged by period for all 160 focal cows (40 from each of the 4 herds) that were observed for $5 \mathrm{~d}$ for each period.

${ }^{2} \operatorname{Ref}=$ reference category

${ }^{3}$ Fresh feed delivery delay $=$ difference in time between individual milking time and closest fresh feed delivery.

${ }^{4}$ Push-up frequency $=$ number of feed push-ups per day.

${ }^{5}$ Odds ratio and $95 \%$ CI for $1 \mathrm{SD}$ in variable presented.

to have longer periods of forced standing. However, given that the cows in this study only had 9 lying bouts per day, it is possible that they remained standing to feed for a longer period of time following milking. In turn, the increased duration of their lying bouts when they do lie down might also be a reflection of time away from the pen for milking. DeVries et al. (2011) and Deming et al. (2013) reported a similar number of daily lying bouts and subsequently longer bout durations when observing freestall-housed cows, milked in a robotic system $>2 \times / d$. The long PMSD and short daily lying durations observed in this study might also be a result of the sampling period occurring in the spring and summer months. Temperature and humidity data were not collected and analyzed in the present study. However, anecdotally, it was a hot and humid summer in southeastern Ontario. Given that previous research has shown reduced lying durations in response to a higher temperature-humidity index, future research should focus on the effect of temperature and season on PMSD to provide further understanding for the increased PMSD in freestall-housed cows milked $3 \times / \mathrm{d}$ (Zahner et al., 2004).

High freestall stocking densities also have the potential to decrease PMSD, because cows may elect to lie down quickly following milking to secure a lying place, rather than access the feed bunk and face increased competition for stalls later on. Fregonesi et al. (2007) observed a 13-min decrease in PMSD when cows were stocked at $150 \%$ compared with those stocked at $100 \%$. Despite a minimal amount of overcrowding in the current study (average 103\%), a negative relationship was observed between PMSD and increased stocking density. This indicates that keeping freestall stocking densities lower is advisable to discourage cows from lying down quickly following milking.

Another factor influencing PMSD is competition at the feed bunk. The mean linear feed bunk space of 0.53 $\mathrm{m} /$ cow in the study herds is below the industry recommendation (0.61 m/cow: Grant and Albright, 2001). Previous research has established that providing more bunk space per cow improves feed access and decreases competition (DeVries et al., 2004; DeVries and von Keyserlingk, 2006; Huzzey et al., 2006). Thus, it is not surprising that increasing feed bunk space was associated with longer PMSD, because cows would be more likely to access the feed bunk following milking if competition is reduced. It is interesting that the relationship between stocking density and feed bunk space was only found for the first daily milking. To our knowledge, this is the first study on PMSD to separately analyze the factors influencing this behavior at each individual milking. However, given that 2 of the farms had only one fresh feed delivery, and one farm that de- 
livered fresh feed $2 \times / \mathrm{d}$ had both deliveries around the first daily milking, we caution the extrapolation of this finding and encourage further research to specifically address this question.

Increasing frequency of feed push-ups was associated with longer PMSD for all 3 daily milkings. Whereas the relationship between provision of fresh feed and PMSD is well-established (Tyler et al., 1997; DeVries and von Keyserlingk, 2005), the effect of feed push-ups on encouraging cows to remain standing is less well understood. DeVries et al. (2011) noted that feedmanipulation (fresh feed delivery and feed push-ups) affected PMSD in AMS cows fed $1 \times / d$ with multiple feed push-ups. Given that cows in that previous study were milked on average $2.4 \times / \mathrm{d}$, it is conceivable that the cows in the present study, under $3 \times / \mathrm{d}$ milking conditions, were similarly stimulated to visit the feed bunk by feed push-ups following milking.

A relationship between the feed manipulation delay and PMSD was only found for the first daily milking. The finding that feed manipulation between $1 \mathrm{~h}$ before milking until $1 \mathrm{~h}$ after milking decreased PMSD as compared with feed manipulation occurring greater than 60 min before milking is contradictory to the findings of DeVries et al. (2011), where, in an AMS herd, feed manipulation between $60 \mathrm{~min}$ before and $120 \mathrm{~min}$ after milking resulted in the longest PMSD. However, the fact that the AMS-milked cows in the DeVries et al. (2011) study did not enter a holding pen before milking could explain these differences. Average premilking standing duration in this study was $106 \mathrm{~min}$. Although the cows were not in the holding pen for the entire time, the holding-pen durations were approximately $60 \mathrm{~min}$ in duration. Thus, if feed was manipulated $>60$ min before milking, cows were likely being stimulated to feed just before being removed from the pen for milking, and this preference continued when they returned from milking. Delivery of fresh feed has been identified as having a greater effect on stimulating feeding behavior than returning from milking; therefore, the coupling of feeding and milking may have resulted in a greater effect (DeVries and von Keyserlingk, 2005).

It is not surprising when looking at the effect of fresh feed delivery in relation to time of milking on PMSD following the first milking that, again, delivery of fresh feed well before milking time (between 1 and $5 \mathrm{~h}$ before milking) produced longer PMSD than delivery of fresh feed 2 to $9 \mathrm{~h}$ after milking. This differs from the effect of fresh-feed delivery on PMSD following the second milking, where increased PMSD were observed when feed was delivered 90 to $180 \mathrm{~min}$ after milking. The majority of focal cows did not receive a second fresh feed delivery; therefore, this finding is indicative of the fact that the provision of a second fresh feed delivery likely has positive effects on PMSD. Although delivering fresh feed 90 to 180 min after milking resulted in increased PMSD, it should be noted that the average cow only stood for 99 min following the second milking. Unfortunately, it is beyond the scope of this study to speculate given that holding-pen times may have affected this relationship. Thus, future studies should seek to further understand the effect of holding-pen time on PMSD in $3 \times / \mathrm{d}$-milked cows.

The factors affecting PMSD at the third daily milking were distinctly different given the failure to identify any associations with factors related to feeding, with the exception of feed push-up frequency. The relationship between PMSD for the third milking and DIM is likely related to production and metabolic requirements, which are expected to be exacerbated under $3 \times / d$ milking conditions. Cows in the current study had a higher mean 305-d milk production, at 11,670 $\mathrm{kg}$, than recently reported in a study of 91 Canadian dairy herds (mean: 9,781 kg; Reyher et al., 2011). This finding may be a result of the current study only using herds milking $3 \times / d$. Furthermore, this observation is in agreement with previous findings that milking $3 \times / \mathrm{d}$ leads to increased milk yield, and increased milk yield has been associated with decreased daily lying durations and increased feeding activity following milking (Allen et al., 1986; Norring et al., 2012). Later-lactation cows may spend less time feeding and more time lying because of lower metabolic requirements, and the reduction in PMSD observed in this study in relation to DIM may be an indicator of less motivation to stay standing to feed following milking, particularly after the third milking of the day (Bewley et al., 2010). Metabolic requirements could also be expected to be driving PMSD following the first and second milkings because cows would remain standing to feed. However, given that cows would generally be expected to be lying down during the time period encompassing the third milking, it is likely that those cows that do remain standing for a long period of time following the third milking are doing so in response to metabolic needs that are overriding any motivation to lie down. Further research with video recording to determine the exact activity of these cows following the third milking is encouraged to enhance the understanding of factors affecting PMSD for the third milking in $3 \times / \mathrm{d}$ milked cows.

As with DIM, the fact that milking order was only associated with PMSD following the third milking was an intriguing finding that warrants further research. To date, no specific link between milking order and effect on PMSD has been found, although DeVries et al. (2011) did report a positive correlation between premilking standing duration and PMSD in AMS cows. Given that cows with a later milking order would 
likely be experiencing increased premilking standing demands, it seems intuitive to expect that they may choose to lie down more quickly following milking. It is also likely that cows further down in the milking order may have less space at the feed bunk available to them upon return from milking. Thus, they may choose to lie down rather than compete for access to feed. At a herd level, cows actively sort for highly palatable starch-rich short and fine TMR particles (Sova et al., 2013). Furthermore, another explanation may be that feed sorting conducted by the cows milked earlier in the order has led to a less-high-quality feed being available to the cows at the end of milking. Thus, the feed may be less enticing, and as a result, the cow milked later may lie down sooner. Therefore, a possible means for farmers to both mitigate competition at the feed bunk and sorting, as well as increase PMSD, may be to have a higher feeding frequency (DeVries et al., 2005; Sova et al., 2013).

The geometric mean annual bulk milk SCC for the study herds of 240,000 cells $/ \mathrm{mL}$ was comparable to the Ontario average of 234,000 cells $/ \mathrm{mL}$ for the period of the study (DFO, 2013). The herd IMI incidence rate of 3.22 new IMI per quarter year is higher than that reported by DeVries et al. (2010, 2011), despite those studies reporting a similar distribution of organisms with predominately CNS and Corynebacterium spp. being cultured. As with DeVries et al. (2010, 2011), milk samples in the present study were frozen before completion of bacteriology. Freezing milk samples has the potential to affect the results of the bacterial culture. Schukken et al. (1989) noted that freezing and storage of milk samples decreased the proportion of samples that were E. coli and T. pyogenes culture positive and increased the proportion of CNS-positive cultures. Staphylococcus aureus was not affected by either freezing or storage, which is in agreement with Godden et al. (2002). However, a more recent study noted no effect of freezing of samples or 6 -wk storage when culturing for 3 species of CNS, E. coli, Staph. aureus, Strep. dysgalactiae, Strep. agalactiae, Strep. uberis, and C. bovis (Murdough et al., 1996). Thus, it is possible that the effect of freezing and storage may have affected the results of this study. Given that the focus of the present study was on CNS, had freezing led to an increase in the proportion of CNS-positive cultures, the potential exists for an effect on incidence of CNS culture-positive cases in this study if comparing with culturing of fresh milk samples (i.e., not frozen). Disagreement exists as to the effect of freezing on CNS (Schukken et al., 1989; Murdough et al., 1996). Had freezing led to an increase in CNS-positive cultures in this study, it would likely be the result of freeing trapped intracellular CNS as cells are destroyed. Thus, the incidence rate determined following freezing of samples could be considered to be more accurate. However, a potential effect on the interpretation of the relationship between CNS IMI and PMSD may exist across studies depending on whether they culture fresh or frozen milk samples. Therefore, future studies should seek to further understand the effect of freezing and storage of milk samples on individual bacterial species to ensure viability for bacteriology. Furthermore, the extrapolation of the results of the present study should be cautioned to account for potential differences when comparing results with studies using fresh milk samples (Reyher et al., 2011).

The collection of $30 \mathrm{~mL}$ of milk for bacteriological culture may also have affected the results of this study. As stated in the methods, this sample volume was determined a priori to ensure a sufficient volume of milk from a single sample for both bacteriology and SCC determination. Following unforeseen circumstances and study limitations, the SCC measurement was abandoned, but the original milk sample size was maintained for consistency. The aseptic collection of $30 \mathrm{~mL}$ of milk has the potential to lead to increased contamination rates given that cows will likely move during the time it takes to sample this volume and that the likelihood of contamination during such an event may be affected by both cow and parlor hygiene conditions. This challenge of collecting a $30-\mathrm{mL}$ aseptic milk sample has previously been noted by Reyher et al. (2011). The effects of PMSD on IMI have the potential to be underestimated in the event of the loss of true infections due to contamination. However, given that the contamination rate was quite low in this study $(1.1 \%)$, it seems unlikely that many true infections were missed because of contamination of samples. Thus, any loss of true infections as a result of contamination because of the volume of milk sample is likely minimal. Also, milk samples were agitated to ensure mixing before bacteriological culture; therefore, the likelihood of any effect due to separation of milk components in the $30-\mathrm{mL}$ sample following freezing and shipping before culturing would also be minimized despite the sample size being larger than that required for bacteriological culturing.

The isolation of focal quarters with positive CNS cultures reported in this study is comparable to several other recent studies (Sampimon et al., 2009; Reyher et al., 2011; Quirk et al., 2012). However, the incidence rate of 1.62 CNS IMI per quarter year is much lower than that recently reported by Dufour et al. (2012; 3.48 CNS IMI per quarter year) in a cohort of $90 \mathrm{Ca}-$ nadian dairy herds. This is not surprising, given that the current study used a threshold of $\geq 500 \mathrm{cfu} / \mathrm{mL}$ for CNS compared with $\geq 200 \mathrm{cfu} / \mathrm{mL}$ by Dufour et al. (2012). Thus, it is possible that some CNS-infected cows were missed by using a more critical threshold 
(higher cfu count) to define the presence of a new CNS IMI. Yet, by being more critical, it was hoped that a higher specificity would improve the identification of actual cases of CNS IMI. It is also possible, given the 28-d cycle of milk sampling, that we missed transient CNS cases; however, by setting our threshold for CNS IMI at $\geq 500 \mathrm{cfu} / \mathrm{mL}$, the likelihood of missing CNS IMI is reduced and the likelihood of excluding transient cases that do not develop into an IMI is increased. Furthermore, Andersen et al. (2010) noted that taking a higher cut-point may decrease the likelihood of misclassification. Therefore, although it is possible that misclassification bias may be affecting the results of this study, the higher cut-points to define an IMI should reduce the likelihood of false positives. However, in the instance that false positives have been included in the data set, the potential exists for overestimation of the incidence rate of CNS IMI and its relationship with PMSD. As a result, this overestimation may lead to an incorrect identification of the critical period of PMSD where odds of CNS IMI were decreased. However, the use of a critical cut-point should have mitigated the likelihood of false positives increasing the number of CNS IMI observed and affecting the relationship with PMSD. This does not, however, account for the high overall IMI incidence rate observed in these cows. The high overall IMI incidence rate may also be a response to the frequency of CNS IMI observed in these herds. It is noteworthy that a potential link between presence of CNS and an in increased incidence of a new major pathogen IMI has been described, but not confirmed, in a previous study (Reyher et al., 2012). However, in this particular study, we did not find a high incidence of major pathogens IMI. Rather, the overall IMI incidence rate was quite high, indicating a potential link between CNS IMI and other mastitis pathogens, major or minor. Further research is necessary to determine whether this relationship is in fact cause and effect or rather a unique finding of the present study. The incidence rate of IMI seen in this study may also be due to the sampling period that took place during the spring and summer months, a time of year noted for increased risk of high SCC and IMI (Makovec and Ruegg, 2003; Olde Riekerink et al., 2007). The high overall IMI incidence rate may also be a result of using a single milk sample to define IMI. This is a limitation of the study. Because of the preliminary nature of the study, and for cost effectiveness, a single culture was used. However, previous research has shown that triplicate sampling provides only modest gains in specificity and little to no improvement in sensitivity (Dohoo et al., 2011).

Given that CNS species predominate in the environment (Piessens et al., 2011), it was not surprising that the final model for factors associated with CNS
IMI included PMSD, fresh feed delivery delay, and frequency of feed push-ups. The tendency of PMSD to be associated with environmental (DeVries et al., 2010) or CNS (DeVries et al., 2011) IMI has been previously established. DeVries et al. (2010) reported a reduced incidence of new environmental IMI in tie-stall herds with a PMSD of 40 to $60 \mathrm{~min}$ and an increased incidence of new IMI as PMSD increased past $60 \mathrm{~min}$. Comparably, in an AMS herd, DeVries et al. (2011) reported an increased incidence of new CNS IMI with a PMSD >150 min. In the present study, reduced incidence of new CNS IMI was associated with PMSD 90 to $120 \mathrm{~min}$. This result is somewhat contradictory to the findings of the aforementioned studies. However, it gives further credence to the idea that different management practices (such as milking frequency) have a varied influence on IMI incidence. Specifically, that PMSD has the potential to be used as both a prevention strategy for IMI and a possible screening tool to indicate at-risk cows. Interestingly, DeVries et al. $(2010,2011)$ noted an increased incidence of IMI with longer PMSD. However, the current study failed to show a relationship between longer PMSD and increased risk of IMI. The decreased risk of IMI when cows stood for 90 to 120 min after milking supports a recent finding by Watters et al. (2013), where a decreased risk of elevated SCC was noted when $3 \times / \mathrm{d}-$ milked cows stood $>90$ min after milking. Previous research on teat-canal morphology has noted that teat-canal width is at a maximum immediately following milking, with a second period of opening being identified 2 to $4 \mathrm{~h}$ following milking (McDonald, 1975; Schultze and Bright, 1983; Neijenhuis et al., 2001). The previous studies relating PMSD to risk of IMI complimented this knowledge of teat-canal morphology with findings that short PMSD and long PMSD were related to increased risk for environmental and CNS IMI (DeVries et al., 2010; DeVries et al., 2011). However, in the present study, the optimal PMSD encompasses that 2-h mark postmilking, indicating that previous knowledge of teat-canal diameter following milking may be less applicable to freestall-housed dairy cows milked $3 \times / \mathrm{d}$ (at $\sim 8$-h intervals). This is a point further highlighted by Neijenhuis et al. (2001) in a study on teat-canal morphology following milking that showed that teat-canal width and length may take $>8 \mathrm{~h}$ to recover postmilking. Thus, further research is needed to understand how teat morphology changes in relation to milking time under $3 \times / \mathrm{d}-$ milking conditions. The findings of the present study indicate that the relationship between PMSD and IMI in $3 \times /$ d-milked herds may be unique and the extended PMSD observed in these cows coupled with a reduced risk for CNS IMI with PMSD between 90 and $120 \mathrm{~min}$. 
The decreased risk of CNS IMI when fresh feed was delivered $60 \mathrm{~min}$ before to $90 \mathrm{~min}$ after milking is likely related to PMSD and cows standing for 90 to $120 \mathrm{~min}$ following milking to access this feed. The second influence of fresh feed delivery $>540$ min following milking is more difficult to interpret. These instances where fresh feed delivery was provided $9 \mathrm{~h}$ after milking took place on farms feeding once per day. In this case, feeddelivery response may mask the feed-manipulation response, which would affect the later milkings. The fact that increased frequency of feed push-ups was associated with decreased likelihood of CNS IMI provides some insight, but more work is needed to disentangle these effects. The decreased risk of CNS IMI as frequency of feed push-ups is increased is likely also tied into PMSD. Increased frequency of feed push-ups may entice cows to the feed bunk following milking as the feed presented is somewhat novel following a feed push-up. Increased feed push-ups may also increase the distribution of feeding activity across the day, and thus reduce competition at the feed bunk at peak feeding periods (i.e., after milking), which could also help promote PMSD.

\section{CONCLUSIONS}

Postmilking standing duration was longer in $3 \times / \mathrm{d}$ milked, freestall-housed cows provided with ample feed bunk space per cow, kept at a lower stall stocking density, milked earlier in the herd milking order, in earlier lactation, and provided with fresh feed in the time period after milking or feed push-up just before being removed for milking. Cows that stood for 90 to 120 min after milking had a decreased incidence of new CNS IMI. Risk for CNS IMI also decreased when fresh feed was provided around the time of milking and with an increased frequency of feed push-ups. In summary, management practices that promote postmilking standing duration for 90 to 120 min, such as providing new feed or pushing-up feed around milking time, providing ample feed bunk space per cow, and keeping freestall stocking densities low, may help to affect udder health through reduced CNS IMI in freestall-housed cows milked $3 \times /$ d.

\section{ACKNOWLEDGMENTS}

We thank the participating producers for allowing us to collect data on their herds. We thank Megan Bruce of the University of Guelph, Kemptville Campus, for her technical help through the data collection and summarizing periods. Financial support for this research was received from the Dairy Farmers of Canada (Ottawa, ON, Canada), the Canadian Dairy Commission
(Ottawa, ON, Canada), and Agriculture and Agri-Food Canada (Ottawa, ON, Canada) through the Canadian Bovine Mastitis Research Network (Saint-Hyacinthe, QC, Canada). This research was also supported through contributions from the Canadian Foundation for Innovation (Ottawa, ON, Canada) and the Ontario Research Fund (Ministry of Research and Innovation, Toronto, ON, Canada).

\section{REFERENCES}

Allen, D. B., E. J. DePeters, and R. C. Laben. 1986. Three times a day milking: Effects on milk production, reproductive efficiency, and udder health. J. Dairy Sci. 69:1441-1446.

Andersen, S., I. R. Dohoo, R. Olde Riekerink, H. Stryhn, and Mastitis Research Workers' Conference. 2010. Diagnosing intramammary infections: Evaluating expert opinions on the definition of intramammary infection using conjoint analysis. J. Dairy Sci. 93:2966-2975.

Bewley, J. M., R. E. Boyce, J. Hockin, L. Munksgaard, S. D. Eicher, M. E. Einstein, and M. M. Schutz. 2010. Influence of milk yield, stage of lactation, and body condition on dairy cattle lying behaviour measured using an automated activity monitoring sensor. J. Dairy Res. $77: 1-6$

Cook, N. B., and K. V. Nordlund. 2009. The influence of the environment on dairy cow behavior, claw health and herd lameness dynamics. Vet. J. 179:360-369.

Cook, N. B., and D. Reinemann. 2007. A toolbox for assessing cow, udder and teat hygiene. Pages 31-43 in Proc. NMC Annu. Mtg. NMC Inc., Verona, WI.

Dairy Farmers of Ontario. 2013. DFO Statistical Handbook 20112012. 28th ed. Dairy Farm. Ontario, Mississauga, ON, Canada.

Deming, J. A., R. Bergeron, K. E. Leslie, and T. J. DeVries. 2013. Associations of housing, management, milking activity, and standing and lying behavior of dairy cows milked in automatic systems. J. Dairy Sci. 96:344-351.

DeVries, T. J., M. G. Aarnoudse, H. W. Barkema, K. E. Leslie, and M. A. G. von Keyserlingk. 2012. Associations of dairy cow behavior, barn hygiene, cow hygiene, and risk of elevated somatic cell count. J. Dairy Sci. 95:5730-5739.

DeVries, T. J., J. A. Deming, J. Rodenburg, G. Seguin, K. E. Leslie, and H. W. Barkema. 2011. Association of standing and lying behavior patterns and incidence of intramammary infection in dairy cows milked with an automatic milking system. J. Dairy Sci. 94:3845-3855.

DeVries, T. J., S. Dufour, and D. T. Scholl. 2010. Relationship between feeding strategy, lying behavior patterns, and incidence of intramammary infection in dairy cows. J. Dairy Sci. 93:1987-1997.

DeVries, T. J., and M. A. G. von Keyserlingk. 2005. Time of feed delivery affects the feeding and lying patterns of dairy cows. J. Dairy Sci. 88:625-631.

DeVries, T. J., and M. A. G. von Keyserlingk. 2006. Feed stalls affect the social and feeding behavior of lactating dairy cows. J. Dairy Sci. 89:3522-3531.

DeVries, T. J., M. A. G. von Keyserlingk, and K. A. Beauchemin. 2005. Frequency of feed delivery affects the behavior of lactating dairy cows. J. Dairy Sci. 88:3553-3562.

DeVries, T. J., M. A. G. von Keyserlingk, and D. M. Weary. 2004. Effect of feeding space on the inter-cow distance, aggression, and feeding behavior of free-stall housed lactating dairy cows. J. Dairy Sci. 87:1432-1438.

Dohoo, I., S. Andersen, R. Dingwell, K. Hand, D. Kelton, K. Leslie, Y. Schukken, and S. Godden. 2011. Diagnosing intramammary infections: Comparison of multiple versus single quarter milk samples for the identification of intramammary infections in lactating dairy cows. J. Dairy Sci. 94:5515-5522.

Dohoo, I., W. Martin, and H. Stryhn. 2009. Veterinary Epidemiologic Research. 2nd ed. VER Inc., Charlottetown, PEI, Canada. 
Dohoo, I. R., and K. E. Leslie. 1991. Evaluation of changes in somatic cell counts as indicators of new intramammary infections. Prev. Vet. Med. 10:225-237.

Dufour, S., H. W. Barkema, L. DesCoteaux, T. J. DeVries, I. R. Dohoo, K. Reyher, J. P. Roy, and D. T. Scholl. 2010. Development and validation of a bilingual questionnaire for measuring udder health related management practices on dairy farms. Prev. Vet. Med. 95:74-85.

Dufour, S., I. R. Dohoo, H. W. Barkema, L. DesCôteaux, T. J. DeVries, K. K. Reyher, J.-P. Roy, and D. T. Scholl. 2012. Epidemiology of coagulase-negative staphylococci intramammary infection in dairy cattle and the effect of bacteriological culture misclassification. J. Dairy Sci. 95:3110-3124.

Dufour, S., A. Fréchette, H. W. Barkema, A. Mussell, and D. T. Scholl. 2011. Effect of udder health management practices on herd somatic cell count. J. Dairy Sci. 94:563-579.

Flower, F. C., and D. M. Weary. 2006. Effect of hoof pathologies on subjective assessments of dairy cow gait. J. Dairy Sci. 89:139-146.

Fregonesi, J. A., C. B. Tucker, and D. M. Weary. 2007. Overstocking reduces lying time in dairy cows. J. Dairy Sci. 90:3349-3354.

Godden, S. M., J. T. Jansen, K. E. Leslie, N. L. Smart, and D. F. Kelton. 2002. The effect of sampling time and sample handling on the detection of Staphylococcus aureus in milk from quarters with subclinical mastitis. Can. Vet. J. 43:38-42.

Gomez, A., and N. B. Cook. 2010. Time budgets of lactating dairy cattle in commercial freestall herds. J. Dairy Sci. 93:5772-5781.

Grant, R. J., and J. L. Albright. 2001. Effect of animal grouping on feeding behaviour and intake of dairy cattle. J. Dairy Sci. 84:E156-E163.

Harmon, R. J., R. J. Eberhart, D. E. Jasper, and B. E. Langlois. 1990. Microbiological procedures for the diagnosis of bovine udder infection. Natl. Mastitis Counc., Arlington, VA.

Hogan, J. S., R. N. Gonzalez, R. J. Harmon, S. C. Nickerson, S. P. Oliver, J. W. Pankey, and K. L. Smith. 1999. Laboratory Handbook on Bovine Mastitis. rev. ed. Natl. Mastitis Counc. Inc., Madison, WI.

Huzzey, J. M., T. J. DeVries, P. Valois, and M. A. G. von Keyserlingk. 2006. Stocking density and feed barrier design affect the feeding and social behavior of dairy cattle. J. Dairy Sci. 89:126-133.

Ito, K., D. M. Weary, and M. A. G. von Keyserlingk. 2009. Lying behavior: Assessing within- and between-herd variation in free-stallhoused dairy cows. J. Dairy Sci. 92:4412-4420.

Johansson, B., I. Redbo, and K. Svennersten-Sjaunja. 1999. Effect of feeding before, during and after milking on dairy cow behavior and the hormone cortisol. Anim. Sci. 68:597-604.

Ledgerwood, D. N., C. Winckler, and C. B. Tucker. 2010. Evaluation of data loggers, sampling intervals, and editing techniques for measuring the lying behavior of dairy cattle. J. Dairy Sci. 93:5129-5139.

Makovec, J. A., and P. L. Ruegg. 2003. Results of milk samples submitted for microbiological examination in Wisconsin from 1994 to 2001. J. Dairy Sci. 86:3466-3472.

McDonald, J. S. 1975. Radiographic method for anatomic study of the teat canal: Changes between milking periods. Am. J. Vet. Res. 36:1241-1242.

Medrano-Galarza, C., J. Gibbons, S. Wagner, A. M. de Passillé, and J. Rushen. 2012. Behavioral changes in dairy cows with mastitis. J. Dairy Sci. 95:6994-7002.

Murdough, P. A., K. E. Deitz, and J. W. Pankey. 1996. Effects of freezing on the viability of nine pathogens from quarters with subclinical mastitis. J. Dairy Sci. 79:334-336.

Neijenhuis, F., G. H. Klungel, and H. Hogeveen. 2001. Recovery of cow teats after milking as determined by ultrasonographic scanning. J. Dairy Sci. 84:2599-2606.

NMC. 2004. Microbiological Procedures for Use in the Diagnosis of Bovine Udder Infection and Determination of Milk Quality. 4th ed. Natl. Mastitis Counc., Verona, WI.

Norring, M., A. Valros, and L. Munksgaard. 2012. Milk yield affects time budget of dairy cows in tie-stalls. J. Dairy Sci. 95:102-108.
Olde Riekerink, R. G. M., H. W. Barkema, and H. Stryhn. 2007. The effect of season on somatic cell count and the incidence of clinical mastitis. J. Dairy Sci. 90:1704-1715.

Pankey, J. W., P. A. Drechsler, and E. E. Wildman. 1991. Mastitis prevalence in primigravid heifers at parturition. J. Dairy Sci. $74: 1550-1552$.

Piessens, V., E. Van Coillie, B. Verbist, K. Supré, G. Braem, A. Van Nuffel, L. De Vuyst, M. Heyndrickx, and S. De Vliegher. 2011. Distribution of coagulase-negative Staphylococcus species from milk and environment of dairy cows differs between herds. J. Dairy Sci. 94:2933-2944.

Quirk, T., L. K. Fox, D. D. Hancock, J. Capper, J. Wenz, and J. Park. 2012. Intramammary infections and teat canal colonization with coagulase-negative staphylococci after postmilking teat disinfection: Species-specific responses. J. Dairy Sci. 95:1906-1912.

Reyher, K. K., I. R. Dohoo, D. T. Scholl, and G. P. Keefe. 2012. Evaluation of minor pathogen intramammary infection, susceptibility parameters, and somatic cell counts on the development of new intramammary infections with major mastitis pathogens. J. Dairy Sci. 95:3766-3780.

Reyher, K. K., S. Dufour, H. W. Barkema, L. Des Côteaux, T. J. DeVries, I. R. Dohoo, G. P. Keefe, J. P. Roy, and D. T. Scholl 2011. The National Cohort of Dairy Farms - A data collection platform for mastitis research in Canada. J. Dairy Sci. 94:1616-1626.

Sampimon, O. C., H. W. Barkema, I. Berends, J. Sol, and T. J. G. M. Lam. 2009. Prevalence of intramammary infection in Dutch dairy herds. J. Dairy Res. 76:129-136.

SAS Institute Inc. 2011. SAS User's Guide: Statistics. Version 9.3. SAS Inst. Inc., Cary, NC

Schepers, A. J., T. J. G. M. Lam, Y. H. Schukken, J. B. M. Wilmink, and W. J. A. Hanekamp. 1997. Estimation of variance components for somatic cell counts to determine thresholds for uninfected quarters. J. Dairy Sci. 80:1833-1840.

Schukken, Y. H., J. A. H. Smit, F. J. Grommers, D. Vandegeer, and A. Brand. 1989. Effects of freezing on bacteriologic culturing of mastitis milk samples. J. Dairy Sci. 72:1900-1906.

Schukken, Y. H., D. J. Wilson, F. Welcome, L. Garrison-Tikofsky, and R. N. Gonzalez. 2003. Monitoring udder health and milk quality using somatic cell counts. Vet. Res. 34:579-596.

Schultze, W. D., and S. C. Bright. 1983. Changes in penetrability of bovine papillary duct to endotoxin after milking. Am. J. Vet. Res. 44:2373-2375.

Sova, A. D., S. J. LeBlanc, B. W. McBride, and T. J. DeVries. 2013. Associations between herd-level feeding management practices, feed sorting and milk production in freestall dairy farms. J. Dairy Sci. 96:4759-4770.

Tyler, J. W., L. K. Fox, S. M. Parish, J. Swain, D. L. Johnson, H. A. Grasseschi, and R. Gant. 1997. Effect of feed availability on postmilking standing time in dairy cows. J. Dairy Res. 64:617-620.

Vasseur, E., J. Rushen, D. B. Haley, and A. M. de Passillé. 2012 Sampling cows to assess lying time for on-farm animal welfare assessment. J. Dairy Sci. 95:4968-4977.

von Keyserlingk, M. A. G., A. Barrientos, K. Ito, E. Galo, and D. M. Weary. 2012. Benchmarking cow comfort on North American freestall dairies: Lameness, leg injuries, lying time, facility design, and management for high-producing Holstein dairy cows. J. Dairy Sci. 95:7399-7408.

Watters, M. E. A., K. M. A. Meijer, H. W. Barkema, K. E. Leslie, M. A. G. von Keyserlingk, and T. J. DeVries. 2013. Associations of herd- and cow-level factors, cow lying behavior, and risk of elevated somatic cell count in free-stall housed lactating dairy cows. Prev. Vet. Med. 111:245-255.

Woolford, M. W., J. H. Williamson, and H. V. Henderson. 1998. Changes in electrical conductivity and somatic cell count between milk fractions from quarters subclinically infected with particular mastitis pathogens. J. Dairy Res. 65:187-198.

Zahner, M., L. Schrader, R. Hauser, M. Keck, W. Langhans, and B. Wechsler. 2004. The influence of climatic conditions on physiological and behavioural parameters in dairy cows kept in open stables. Anim. Sci. 78:139-147. 